\title{
The Relationship between Working Capital Management and Profitability: A Case Study of Cement Industry in Pakistan
}

\author{
Ikram ul Haq \\ Muhammad Sohail \\ Khalid Zaman * \\ Zaheer Alam \\ COMS ATS Institute of Information Tecbnology, Abbottabad, Pakistan \\ * (Corresponding Author) E-mail: khalidzaman@ciit.net.pk.Khalid_zaman786@yahoo.com
}

\begin{abstract}
This study empirically examines the relationship between working capital management and profitability by using data of fourteen companies in cement industry in the Khyber Pakbtonkhuwa Province (KPK) of Pakistan. The study is based on secondary data collected from financial reports which is listed in Karachi Stock. Exchange for the period of six years from 2004-2009. The data was analyzed using the techniques of correlation coefficient and multiple regression analysis. All the findings were tested at 0.01 and 0.05 level of significance. The result concludes that there is a moderate relationship between working capital management and profitability in the specific context of cement industry in Pakistan.
\end{abstract}

Keywords: Working capital, corporate profitability, financial ratios, multiple regression, cement industry, Pakistan

\section{Introduction}

Cement Industry is one of the major industries of Pakistan. Pakistan is rich in cement raw material. Currently many cement plants are operating in private sector. Pakistan Cement Industry has huge potential for export of cement to neighboring countries like India, U.A.E, Afghanistan, Iraq \& Russian States. There has been a robust growth of cement demand seen both in domestic and exports market during the last decades. The industry achieved an overall growth of $32 \%$ with domestic demand of cement increased by $24.95 \%$ whereas the exports increased by $111.86 \%$. The overall growth achieved by many cement factories for the year 2007-08 was $111.29 \%$ consisting of domestic and export markets at $71.02 \%$ and $335.12 \%$ respectively. Pakistan Cement industry has been successful to capture export markets of various African countries which are new markets for the Country other than the conventional export markets of Afghanistan and Iraq (Pakistan cement industry report, 2008). Figure 1 shows year-wise industry growth from 2002 to 2007.

Management of working capital is an important component of corporate financial management because it directly affects the profitability of the firms. Management of working capital refers to management of current assets and of current liabilities (Reheman and Nasr, 200). Working capital is the amount of fund invested in the current assets of a business. Working capital consists of permanent working capital and temporary working capital. As the name implies, permanent working capital means "the amount of current assets required to meet the firm long term minimum requirement" (Van horn, 2005 .p205). While, temporary or seasonal working capital means "the amount of current assets that varies with seasonal requirement" (Van horn, 2005 .p206). 
Figure 1. Growth in Cement Industry of Pakistan

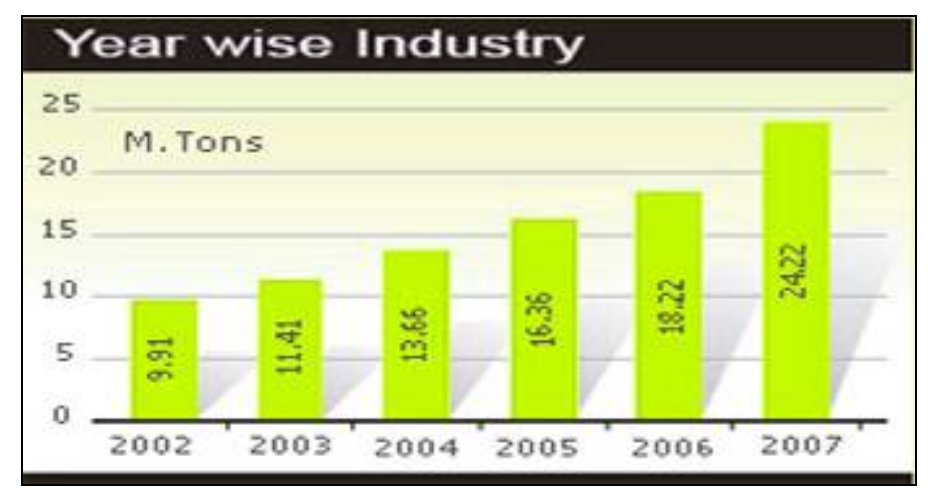

Source: Pakistan cement industry report (2008).

Narware (2004) studied a relationship of working capital and profitability with the help of accounting ratio and statistical tools and finds that there is significant relationship exist between profitability and working capital. Reheman \& Nasr (2007) studied this relationship with different accounting ratios. They find a negative relationship between liquidity $\&$ profitability and debt $\&$ profitability, while positive relationship between size of the firm and its profitability.

In this study an effort has been made to analyze the empirical study of cement industry of Pakistan for examining the effect of working capital on profitability during the period of 2004 to 2009. The more specific objectives are:

- To analyze the effect of working capital on the profitability of the firm.

- To examine the collective impact of the ratio rating with working capital management and profitability and

- To study the working capital leverage for analyzing the sensitivity of return on investment on the level of working capital.

The paper is organized as follows: after introduction which is provided in Section 1 above, literature review is carried out in Section 2. Data and Methodological framework is explained in Section 3. Results are shown in Section 4. Final section concludes the study.

\section{Literature Review}

Efficient management of working capital is essential for the profitability of the firm. Various studies have been conducted to test the relationship of working capital management with profitability. According to Smith (1980), working capital management affects the profitability and risk factor of the firms, and hence resulting increase in the value of firms. Soenen (1993) examined this relationship on US firms and finds that there is negative relationship of net trade cycle length with return on investment. Jose et al. (1996) studied relationship between cash conversion cycle and profitability which showed significant negative relationship exists between them. With expanded sample size and time period, Shin and Soenen (1998) investigated a large sample of 58,985 US firms for the period of 20 years i.e.1975-1994, they concluded that firm's net trade cycle has significant negative relationship with its profitability.

Deloof (2003) has taken a sample of 1009 non-financial firms of Belgium. Results showed that there is negative relationship between day's receivables and inventory with gross operating profit. It is suggested that managers can enhance profitability by increasing day's payables and shortening day's receivables and inventories. Study conducted by Eljelly (2004) on a sample of Saudi listed companies revealed that there is a significant negative relation between the cash gap and profitability. Similarly by investigating a sample of 131 listed firms at Athens Stock Exchange by Lazaridis and Tryfonidis (2006) also found Hutchison et al.(2007) also found 
in an examination of 22000 firm that short Cash Conversion Cycle has direct correlation with profitability.

Ganesan (2007) examine 349 firms from Telecommunication \& Equipment industry over the period of 2001-2007 stated that although, negative relationship exists between firms working capital efficiency and their profitability but was not significant in the said industry. Uyar (2009) analyzed 166 Turkish corporation registered with Istanbul Stock Exchange to find the relationship of Cash Conversion Cycle with profitability and size for the year 2007. The result shows that Cash Conversion Cycle has strong negative relationship with size and profitability of the firms. In a recent study Azhar \& Noriza (2010) have randomly selected 172 Malaysian firms to evaluate the effect of Working Capital Management on the firm profitability and market value. Results show a strong negative association in working capital variables and firms performance. By analyzing the oil and gas sector of Pakistan, Shah and Sana (2006) concluded that there exists a negative relationship between Gross Profit and working capital ratios except average payment period which is positively related to gross profit.

Reheman and Nasr (2007) studied the impact of working capital management on the profitability of the firm by taking a sample of 94 listed companies at KSE for the period of 6 years (1999-2004). They used average collection and payment period with current ratio, inventory turnover and Cash Conversion Cycle as working capital management polices and size, debt ratio and fixed asset ratio as control variables. They found a significant negative relationship in the WCM and the profitability of the firms. A sample size of 263 listed public limited companies at Karachi Stock Exchange were investigated from 1998 to 2003 by Afza and Nazir (2007), the result showed a negative impact of working capital policies on firms profitability. In line to their previous study, Nazir AND aFZA (2009) by adding the risk factor and Tobin's q, investigated 204 listed Pakistani firms at KSE and validate the earlier results.

\section{Data Source and Methodological Framework}

The panel data set covers a 6-year period from 2004 to 2009, with a sample of 14 cement firms of Pakistan. The data were taken from the financial statements of the respective cement firm. The ratios relating to working capital management have been selected and computed for the study i.e.,

i) Current Ratio (CR)

ii) Liquid Ratio (LR)

iii) Current assets to Total assets ratio( CATAR)

iv) Current assets to total sales ratio (CTSR)

v) Cash Turnover (CTR)

vi) Inventory Turnover Ratio (ITR)

vii) Debtor Turnover Ratio (DTR)

viii) Creditor Turnover Ratio (CTR)

For examining the sensitivity of Return on investment (ROI) to changes in the level of working capital, Working capital leverage has been calculated. All statistical calculation had done through SPSS. Table 1 below summarizes the definitions and theoretical predicted signs. Note that previous studies provide no clear-cut direction of the relationship between any of the variables and firm's profitability. 
Table 1. Proxy variables definition and predicted relationship

\begin{tabular}{|c|c|c|c|}
\hline Dependent variable & Definition & Symbols & Expectation \\
\hline Return on investment & $\begin{array}{l}\text { Compare measure of benefits such as earning } \\
\text { or net income on total investment made in } \\
\text { business. }\end{array}$ & ROI & \\
\hline \multicolumn{4}{|l|}{ Independent variables } \\
\hline Current Ratio & $\begin{array}{l}\text { Describe the firm ability to meet its or cover } \\
\text { its current liabilities using its current assets. }\end{array}$ & CR & Negative \\
\hline Liquid ratio & $\begin{array}{l}\text { Describe the firm ability to meet its or cover } \\
\text { its current liabilities using its current assets } \\
\text { excluding inventories. }\end{array}$ & LR & Negative \\
\hline $\begin{array}{l}\text { Current assets to total } \\
\text { assets ratio }\end{array}$ & $\begin{array}{l}\text { Describe the ratio of current assets to total } \\
\text { Assets of the firm. }\end{array}$ & CATAR & Negative \\
\hline $\begin{array}{l}\text { Current Assets to sales } \\
\text { ratio }\end{array}$ & $\begin{array}{l}\text { Describe the ratio of current assets to total } \\
\text { sales revenue. }\end{array}$ & CASR & Negative \\
\hline Cash Turnover Ratio & Describe the ratio of sales to cash. & CTR & Positive \\
\hline Debtors turn over ratio & $\begin{array}{l}\text { Describe the efficiency of debtors to be } \\
\text { converted into cash. }\end{array}$ & DTR & Positive \\
\hline Inventory turn over ratio & $\begin{array}{l}\text { Describe the efficiency of inventory to be } \\
\text { converted into C.G.S. }\end{array}$ & ITR & Positive \\
\hline Credit turnover ratio & Describe the efficiency of creditors to be paid. & CRTR & Negative \\
\hline
\end{tabular}

The basic estimation strategy is to pool the observations across banks and apply the regression analysis on the pooled sample. That is, a pooled OLS (POLS) equation will be estimated in the form of:

$Y_{i t}=\beta_{0}+\beta_{1} X 1_{i t}+\beta_{2} X 2_{i t}+\beta_{3} X 3_{i t}+\beta_{4} X 4_{i t}+\beta_{5} X 5_{i t}+\beta_{6} X 6_{i t}+\beta_{7} X 7_{i t}+\beta_{8} X 8_{i t}+u_{i t}$

Where

- $Y_{i t}$ represents Return on Investment (ROI) for firm $i$ at time $t$.

- $X 1_{i t}$ represents current ration (CR) for firm $i$ at time $t$.

- $X 2_{i t}$ represents liquid ratio (LR) for firm $i$ at time $t$.

- $X 3_{i t}$ represents current assets to total assets ratio (CATAR) for firm $i$ at time $t$.

- $X 4_{i t}$ represent current assets to sales ratio (CASR) for firm $i$ at time $t$.

- $X 5_{i t}$ represents cash turn over ratio (CTR) for firm $i$ at time $t$.

- $X 6_{i t}$ represents debtors turn over ratio (DTR) for firm $i$ at time $t$.

- $X 7_{i t}$ represents inventory turn over ratio (ITR) for firm $i$ at time $t$.

- $X 8_{i t}$ represents credit turn over ratio (CRTR) for firm $i$ at time $t$.

- $i=1$ to 14 firms

- $t=2004-2009$

- $u_{i t}=$ Error term.

The advantage of pooling is that more reliable estimates of the parameters in the model can be obtained. It is a valid procedure where the relationship between the variables is stable across cross-section units. Our data set gives evidence that cement industry shows similar response to cyclical movements. Therefore, we believed that the relationship between working capital management and profitability are stable across firms and that is why we decided to apply pooled OLS estimation method. 


\section{Results and Discussion}

This section deals with the results of the study which include the descriptive statistics, econometric results and tests for multi-collinearity which is relevant for the study. The descriptive statistics are calculated and presented in Table 2 for ready reference.

Table 2. Descriptive Statistics $(N=84)$

\begin{tabular}{|c|c|c|}
\hline Variables & Mean & Std. Deviation \\
\hline ROI & 0.0725 & 0.1270 \\
\hline CR & 1.0441 & 0.6556 \\
\hline LR & 0.9410 & 0.6439 \\
\hline CATAR & 0.3019 & 0.1802 \\
\hline CASR & 0.7675 & 2.1885 \\
\hline CATR & 62.0062 & 97.3217 \\
\hline DTR & 5.3829 & 4.1451 \\
\hline ITR & 32.2297 & 49.5554 \\
\hline CTR & 1.9084 & 1.2578 \\
\hline
\end{tabular}

Table 3 provides the Pearson correlation for the variables that we used in the regression model. Pearson's correlation analysis is used for data to find the relationship between working capital management and profitability. We found that the return on investment is negatively correlated with the current assets to sales ratio (CASR) and cash turn over ratio (CTR). While, ROI is positively correlated with the current ratio (CR), liquid Ratio (LR), current assets to total assets ratio (CATAR), debtors turn over ratio (DTR), inventory turn over ratio (ITR) and credit turn over ratio (CTR). However, ITR has a very weak correlation with ROI.

Table 3. Pearson Correlation matrix

\begin{tabular}{|l|c|c|c|c|c|c|c|c|c|}
\hline & CR & LR & CATAR & CASR & CTR & DTR & ITR & CTR & ROI \\
\hline CR & 1.000 & & & & & & & & \\
\hline LR & $.989^{* *}$ & 1.000 & & & & & & & \\
\hline CATAR & $.677^{* *}$ & $.674^{* *}$ & 1.000 & & & & & & \\
\hline CASR & -.040 & -.023 & -.074 & 1.000 & & & & & \\
\hline CATR & $-.267^{*}$ & $-.294^{* *}$ & -.208 & -.053 & 1.000 & & & & \\
\hline DTR & -.025 & -.063 & .009 & -.189 & $.557^{* *}$ & 1.000 & & & \\
\hline ITR & -.085 & -.042 & -.052 & -.097 & .051 & .025 & 1.000 & & \\
\hline CTR & $.476^{* *}$ & $.406^{* *}$ & $.356^{* *}$ & $-.237^{*}$ & -.204 & $.235^{*}$ & .061 & 1.000 & \\
\hline ROI & $.333^{* *}$ & $.318^{* *}$ & $.410^{* *}$ & -.118 & $-.305^{* *}$ & $.352^{* *}$ & .053 & $.520^{* *}$ & 1.000 \\
\hline
\end{tabular}

Note: $*$ and $* *$ indicates correlation is significant at the 0.05 and 0.01 level (2-tailed). .

The model for the working capital management and firm's profitability is selected on the basis of strong diagnostics and high value for the R-squared. The results are represented in Table 4. 
Table 4. Pooled Least Square. Dependent variable $=$ ROI

\begin{tabular}{|l|c|}
\hline Variables & Coefficients \\
\hline Constant & $-12.79^{*}$ \\
\hline CR & $0.610^{*}$ \\
\hline LR & $0.684^{*}$ \\
\hline CATAR & $0.248^{* *}$ \\
\hline CASR & -0.104 \\
\hline CTR & $-0.352^{*}$ \\
\hline DTR & $0.814^{*}$ \\
\hline ITR & 0.143 \\
\hline CTR & $0.491^{*}$ \\
\hline R-square & 0.588 \\
\hline Adjusted R-squared & 0.542 \\
\hline F-statistics & $13.384^{*}$ \\
\hline
\end{tabular}

Note: * and ${ }^{* *}$ shows significance at the 0.01 and 0.05 level.

The value for the $\mathrm{R}$-squared in the model is 0.588 which endorses that $58.8 \%$ of the variation in the dependent variable is explained by the independent variables of the model. The $41.2 \%$ variation in the dependent variable remains unexplained by the independent variables of the study. The value for the F-statistic is 13.384 and is significant endorsing the validity and stability of the model relevant for the study. The results of other diagnostics suggest that the CR, LR, CATAR, DTR and CTR have a significant positive relation with ROI. This positive relationship shows that working capital management except ITR has significant positive impact on profitability of the cement industry in Pakistan. It suggests that larger firms achieve a higher ROI. On the other hand, CASR and CTR both have a negative impact on ROI. However, CASR relationship is insignificant with ROI, the relationship is not conclusive.

The test to detect multicollinearity (variance inflation factor) is also performed to support the validity of the regression results. In case of VIF, if the result is below the 10 and Tolerance near to zero suggest no multicollinearity (Gujrati, 2003). In Table 5 results of VIF and tolerance factor is reasonably good. The values of variance inflation factor for the variables in the model ranges from 1.012 to 2.741 for CTR to CASR suggesting the absence of multicollinearity among the variables of the model.

Table 5. V alues of Tolerance and Variance Inflation Factor (VIF)

\begin{tabular}{|l|c|c|}
\hline Variables & Tolerance & Variance Inflation Factor \\
\hline CR & 0.701 & 1.452 \\
\hline LR & 0.805 & 1.982 \\
\hline CATAR & 0.749 & 2.124 \\
\hline CASR & 0.844 & 2.741 \\
\hline CTR & 0.833 & 1.012 \\
\hline DTR & 0.764 & 1.309 \\
\hline ITR & 0.822 & 1.216 \\
\hline CTR & 0.850 & 1.177 \\
\hline
\end{tabular}

\subsection{Robustness Test}

a) Incremental regression

The incremental regression is performed by removing individual independent variables from the model and by checking the effect on the value of R-squared. Among all the variables 
removed, DTR has altered the value of R-squared to a highest degree (29\% decreases in the portion of the dependent variable explained by independent variables) as the value for the $\mathrm{R}$ squared changes from $58.8 \%$ to $29.8 \%$. This substantial decrease in the value of the R-squared shows the importance of DTR in the model. This importance is also highlighted in the regression result as the value of coefficient of the variable (0.814) is highest among all the variables. The result is presented in Table 6 .

Table 6. Results of Incremental Regression removing DTR

\begin{tabular}{|l|c|}
\hline Models & R-value \\
\hline R-squared (Original) & 0.588 \\
R-squared (after the removal) & 0.298 \\
\hline
\end{tabular}

b) Endogeneity Test

The second robustness test used in this study is the test for endogeneity. This test is performed to make the results of the study robust. The possibility of reverse causation from Debt to Asset Ratio (DTR) to firm's profitability (ROI) is raised by the extensive literature. Where such a relationship exists it raises the possibility of endogeneity in our model. In the first step of this process, the relationship of the ROI with their independent variables is tested and the error term (residual) is calculated. In the second step, the relationship of the ROI with the independent variables including the calculated error term (residual) on first lag is tested. We have found no relationship of residual with the ROI which shows that there is no endogeneity in our model. The result is presented in Table 7.

Table 7. Pooled Least Square Endogeneity Test. Dependent Variable = ROI

\begin{tabular}{|l|c|}
\hline Variables & Coefficients \\
\hline Constant & $-7.14^{*}$ \\
\hline CR & $0.625^{*}$ \\
\hline LR & $0.676^{*}$ \\
\hline CATAR & $0.287^{* *}$ \\
\hline CASR & -0.145 \\
\hline CTR & $-0.397^{*}$ \\
\hline DTR & $0.839^{*}$ \\
\hline ITR & 0.157 \\
\hline CTR & $0.512^{*}$ \\
\hline Residuals & 0.357 \\
\hline R-square & 0.678 \\
\hline Adjusted R-squared & 0.649 \\
\hline F-statistics & $1.987^{*}$ \\
\hline
\end{tabular}

Note: * and ${ }^{* *}$ shows significance at the 0.01 and 0.05 level.

\section{Summary and Conclusion}

This paper examines the relationship between working capital management and firm's profitability of fourteen firms listed at Karachi Stock Exchange. The main objective of the study was to find whether financial ratios affect the performance of the firms in the special context of cement industry in Pakistan. The result concludes that there is a moderate relationship between working capital management and firm's profitability. Future research should investigate generalization of the findings beyond the Pakistan manufacturing sector. The scope of further 
research may be extended to the working capital components management including cash, marketable securities, receivables, and inventory management.

\section{References}

Afza T., \& Nazir, M.S. (2007). Is it better to be aggressive or conservative in managing working capital? Paper presented at Singapore Economic Review conference (SERC) on August 02-04, Singapore.

Uyar, A. (2009). The Relationship of Cash Conversion Cycle with Firm Size and Profitability: An Empirical Investigation in Turkey. International Research Journal of Finance and Economics, Issue 24 (2009).

Azhar \& Noriza (2010). Working Capital Management: The Effect of Market Valuation and Profitability in Malaysia. International Journal of Business and Management Vol. 5, No. 11; November 2010.

Deloof, M. (2003). Does Working Capital Management Affects profitability of Belgian Firms? Journal of Business Finance \& Accounting. 30(3) \& (4), 306-686.

Eljelly, A. (2004). Liquidity-Profitability Tradeoff: An empirical Investigation in an Emerging Market. International Journal of Commerce \& Management, Vol 14,No 2 ,pp. 48 - 61.

Gujarati, D. (2003). Basic Econometrics (4th edn). New York: McGraw-Hill.

Hutchison, P. D., Farris II, M. T. and Anders, S. B., (2007). Cash-to-cash analysis and management. The CPA Journal, Vol. 77 No. 8, pp. $42-47$.

Jose, M. L., C. Lancaster, and J. L. Stevens, (1996). Corporate Returns and Cash Conversion Cycles. Journal of Economics and Finance. 20(1), 33-46.

Van Horn, J. C. (2005). Fundamental of Financial Management, $12^{\text {th }}$ edition, National Book Foundation Pakistan.

Lazaridis, I. and D. Tryfonidis, (2006). Relationship between Working Capital Management and Profitability of Listed Companies in the Athens Stock Exchange. Journal of Financial Management and Analysis. 19 (1), $26-35$.

Nazir, M. S. and Afza, T. (2009). Impact of Aggressive Working Capital Management Policy on Firms' Profitability. The IUP Journal of Applied Finance, Vol. 15, No. 8, 2009

Narware P. C. (2004). Working capital and profitability- an empirical analysis. The Management Accountant, Vol, 39 (6), pp 120-127.

Pakistan cement industry (2008). Final cement industry report, online available at: http://www.cement.com.pk/ cement / pakistan-cement-industry.html

Raheman, A. and M. Nasr, (2007). Working Capital Management and Profitability - Case of Pakistani Firms. International Review of Business Research Papers, 3 (2), 275 - 296.

Shah, A. and A. Sana, (2006). Impact of Working Capital Management on the Profitability of Oil and Gas Sector of Pakistan. European Journal of Scientific Research. 15(3), 301 - 307.

Shin, H., and L. Soenen, (1998). Efficiency of Working Capital and Corporate Profitability. Financial Practice and Education, 8(2), 37-45.

Soenen, L.A. (1993). Cash Conversion Cycle and Corporate Profitability. Journal of Cash Management, 13, 53-57

Smith K (1980). Profitability versus Liquidity Tradeoffs in Working Capital Management in Readings on the Management of Working Capital. New York: St. Paul, West Publishing Company.

Ganesan, V. (2007). An analysis of working capital management Efficiency in telecommunication equipment Industry. Riviera academic journal, volume 3, number 2, fall 2007. 